\title{
Communicating Value to Enhance Service Visualization
}

\author{
Vai Leong, Universiti Brunei Darussalam \\ Sally A. Hibbert, University of Nottingham \\ Christine Ennew, Warwick University
}

\begin{abstract}
Purpose - This study aims to examine the effects of enhanced visualization of intangible service value through integration of means-end perspectives on advertising effectiveness.

Design/methodology/approach - Banking advertisements, incorporating message stimuli derived from salient values desired by the financial consumers and designed to assist message elaboration and stimulate personal relevance, were developed to examine the influence of cognitive connectivity on vividness of intangible service benefits and service advertising effectiveness.
\end{abstract}

Findings - The findings demonstrate that greater cognitive connectivity positively affects perceived tangibility, attitude towards the advertisement, and attitude towards the brand. Additionally, the results indicated that perceived personal relevance has higher influence on envisioning service components, compared to one's ability to connect visual cues to perceived benefits and to immediate end-goals.

Research limitations - This study incorporated visual stimuli limited only to financial security and social recognition. Future research should aim to examine the effects of different type of values on consumers' elaboration process and their ability to visualize financial services.

Originality/value - This study extends knowledge of the means-end chain by proposing a means-end cognitive connectivity (MECC) construct which influences the degree that consumers are able to mentally picture intangible service attributes. This study also provides insight that different values have different degree of influence on one's ability to visualize service.

Keywords Intangibility, financial services, values, visualization strategy, advertising, meansend chain

Paper type Research paper 


\section{Introduction}

The services marketing literature has long recognized intangibility, described as 'inaccessible to the senses', such that consumers find it difficult to conceptualize services both physically and mentally (Bateson, 1979; Hirschman, 1980). Berry (1980) asserts that consumers face difficulty envisaging service benefits (mental intangibility), and this mental intangible property makes it challenging for consumers to form expectations of service (Tarn, 2005), intensifies the difficulty of evaluation and heightens perceived risk (Laroche et al., 2003).

Contemporary service research, has questioned whether it is useful to draw the distinction between tangible goods and intangible services, given the argument within service-dominant logic (Vargo and Lusch, 2004) that neither goods and services have properties that are intrinsically valuable to consumers, rather they render value-in-use when deployed by consumers (Lovelock and Wirtz, 2004). Yet scholars argue that intangibility merits continued attention because consumers themselves draw distinctions between tangible and intangible offerings (Rosenzweig and Gilovich, 2012), new categories of service being offered to consumers are highly intangible (Laroche et al., 2001) and because it affects the consumer experiences that influence their behavior and value outcomes at each stage of the consumption cycle (Hellén and Gummerus, 2013).

Advertising is a primary means of making a service, as imagined by consumers, more vivid thus counteracting intangibility (Devlin et al., 2002). Scholars have long been intrigued by questions about the effects of message elements to overcome service intangibility and implications for advertising effectiveness, and there have been calls for further research on creation and communication of value to the service consumers (Stafford, 2005; Mortimer, 2008; Payne et al., 2008). The small body of extant research has provided insights into the types of physical representations (cues and message content) that impact service advertising effectiveness, but the connection with consumer value has been neglected (Kindström et al., 2012). The consumer behavior literature and, more recently, service research has recognized 
that value is a central driver of consumer choice and behaviors (Woodruff, 1997; Gummerus, 2013). Service providers have to understand how consumers create value and how they can support and facilitate their service consumption (Grönroos and Gummerus, 2014). Identifying the different type of value that consumers derive from service usage can help service managers to make effective decisions on service process, design and communication (Klanac, 2013).

Managers may question how and why consumers are able to better understand and prefer certain advertisements over others. Mulvey et al. (1994) explained that personal relevance emerged when consumers are able to link product attributes to achieve their personal values, and thus, in a better position to devote attention to elaborate product features and benefits. Therefore, this study aims to address a key research question: How does message content in service advertising help consumers to construe and connect visual elements to attain personal values, and improve advertising effectiveness? Findings from this study will demonstrate that appropriate visual elements trigger consumers to go through a cognitive process of connecting tangible cues to achieve end-goals, and at the same time, perceive an advertised product to be personally relevant to themselves. This mental process of cognitive connectivity facilitates better visualization of services and improves service advertising. By demonstrating the role and importance of tangible cues on eliciting consumers to link visual displays in service advertising to personal values and activating personal relevance which subsequently improve service vividness, this study seeks to contribute to the knowledge base of visualization processes in the service literature.

This study uses a means-end theory (Gutman, 1982) and argues that service advertising effectiveness can be improved by deploying visualization strategies (Berry and Clark, 1986) designed to help consumers envisage links to the value that they hope to derive. The purpose of this study is twofold: (i) to demonstrate that consumers link advertising cues 
with value through 'cognitive connectivity' which enhance service visualization, and (ii) to investigate the influence of a means-end chain connectivity (MECC) concept on perceived tangibility and advertising effectiveness. The paper starts with a literature review of advertising strategies designed to increase service tangibility, followed by means-end chain concept and its links to message elaboration. The next section outlines the research hypotheses that explain the relationship between a means-end visualization strategy in advertising and advertising effectiveness. The following section then explains the method adopted for the empirical research, followed by the findings using structural equation modelling (SEM) applied to test the research hypotheses. The paper concludes with a discussion on the theoretical and practical implications of adopting visualization strategies that enable cognitive connectivity to value, followed by limitations of the study and suggestions for future research directions of the research findings.

\section{Literature Review}

\section{Services Advertising: Designing Message Content to Tangibilize Service}

There is considerable evidence that increasing service vividness enhances consumers' understanding of service features and benefits, facilitates evaluation, reduces perceived risks and elicits favorable responses (Abernethy and Butler, 1992; Pickett et al., 2001, Song and Kim, 2012). Prior studies of visual elements in services advertising have examined message content to test advertising effectiveness of services. It has been proposed that service advertisements should be information-laden because consumers often seek information or tangible evidence of a service prior to purchase to mitigate perceived risks (George and Berry, 1981; Murray, 1991). However, analyzing the informational content of service advertisements, Abernethy and Butler (1992), Abernethy et al., (1997) and Mortimer (2000) reported that service advertising contains less factual information (such as: price, quality, 
performance, availability, components, etc.) compared to advertisements for physical goods. This may reflect the greater use of imagery to help consumers to envisage the relevance of services and apply evaluative criteria (Stern and Resnik, 1991). For instance, Zinkhan et al., (1992) reported that service managers employ more transformational appeals to convert service experiences into a set of positive psychological characteristics during advertising to reduce consumers' perceived risk; and Cutler and Javalgi (1993) concluded that services tend to make more use of emotional advertising strategies.

Some experimental studies have revealed important insights into visual strategy to enhance service advertising effectiveness. Stafford and Day (1995) found that rational advertising generated high levels of positive attitudes towards advertisements for fine-dining and photo-processing services, but had no significant effect on attitude towards the brand. On the other hand, Matilla (1999) reported that emotional appeals positively influence attitudes towards a service provider, service expectations and future purchase intention for hotels. Stafford (1996) tested print advertising strategy for experience and credence services, and found that textual tangible cues enhance recall, positive attitudes, and patronage intentions for services. Examining the effects of visualization strategy and documentation strategy in print advertisements, Hill et al., (2004) concluded that a visualization strategy conveys vivid images of service benefits, resulting to higher level of perceived informativeness, better service quality, and higher patronage intention for services. Clow et al., (2006) found that visual cues influence consumers' evaluation of service quality and source credibility, which positively impact attitude towards the advertisement and purchase intentions. Adopting between-subjects experimental designs, Zhang et al., (2014) reported that emotional advertisement increases purchase intention for experience services, while rational appeal led to higher purchase intention for credence services. More recently, Décaudin and Lacoste (2016) revealed that portrayal of customers improves advertising effectiveness for utilitarian 
and hedonic services, as this type of cue enables customers to relate themselves to the advertised service.

The above studies point out that different visual elements in service advertising plays important roles in consumers' evaluation of services, and their subsequent influence on advertising effectiveness; however, there has been little attention to how these tangible elements may facilitate visualization processes for services, and create connections to service value. It is a crucial issue for further investigation, particularly in sectors that rely upon advertising strategies that focus upon consumer benefits (Décaudin and Lacoste, 2010). Therefore, this study seeks to investigate consumers' cognition of tangible cues in service advertising, and their interpretations of these visual elements into benefits and values, on service vividness and advertising effectiveness.

\section{Means-End Value Chains: Creating Connections through Message Content}

The means-end chain framework is grounded in cognitive psychology and was originally developed as a way to examine the inferences that individuals make about product attributes (Olson and Reynolds, 1983). It holds that consumers direct their behavior to achieve desired consequences (or minimizing undesired ones), guided by end-states (values) that underpin their evaluations (Gutman, 1982, 1997). The knowledge hierarchy can be primed from any level in the chain (Grunert and Grunert, 1995) and the interconnections between various means-end elements can vary and may connect to single or multiple end goals (see: Botschen et al., 1999; Klanac, 2012).

Analysis of the cognitive connections that consumers make between different meansend elements reveals the inferences that they make, and why an offering is perceived to be personally relevant. Personal relevance refers to the extent that consumers believe an offering is congruent to their inner-self values or is instrumental to satisfy personal goals (Celsi and 
Olson, 1988), and which influences cognitive processes and subsequent behavioral responses to a message (Petty and Cacioppo, 1981; Petty et al., 1983). Consumers who become involved in a message and perceive it be self-relevant (Batra and Ray, 1985) will be motivated to elaborate on and attend to product-related information in advertisements (Celsi \& Olson, 1988). They are also able to infer complete means-end associations during processing of product-related information in advertising (Mulvey et al., 1994; Houston and Walker, 1996; Graeff, 1997). That is, complete means-end linkages reflect consumers' commitment to understand and articulate the specific meaning of attributes to attain desired forms of value.

It is widely agreed that insight into the links between attributes, benefits and personal goals helps marketers to develop more effective communication strategy (Gutman and Miaoulis, 2003). Prior research has applied the means-end chain in developing advertising copy and/or evaluating advertising strategy for physical goods (e.g., Gengler and Reynolds, 1995; Jaeger and MacFie, 2001; Reynolds and Rochon, 1991); stressing that salient attributes linked to values should be emphasized in advertisements to help consumers relate the offering to their personal goals. In the service context, the means-end chain has been used to examine service quality of specialty clothing stores (Botschen et al., 1999), motivational factors for travel or leisure destinations (Klenosky et al., 1999; Ho et al., 2014; Jiang et al., 2015), and evaluate goal hierarchical structure for e-services (Heinze et al., 2017; Kuisma et al., 2007; Pai and Arnott, 2013). The above studies have revealed important attributesbenefits-values that consumers associate with the various services, however, inquiries applying means-end approach to examine the extent of these linkages in service advertising are lacking. Research into the potential of a visualization strategy, using hierarchical meansend elements to understand consumers' elaboration process, promises insights on the type of 
tangible cues that may reduce service intangibility and enhance advertising effectiveness; and this would add value to the knowledge base of service advertising.

\section{Conceptual Framework and Hypotheses Development}

The current study responds to calls for further insight on ways to tangibilize service offerings (Kindström et al., 2012) and the effects of visual cues on subsequent consumer responses (McQuarrie and Phillips, 2005) This study proposes a means-end chain connectivity (MECC) concept that explains tangible cues in advertisements can trigger a psychological process of means-end chain connection which serves to tangibilize service and enhances advertising effectiveness. The main proposition is that tangible cues relevant to consumers' means-end value chains trigger a chain of reactions in the consumers' mind, where (i) attributes stimulate higher-order means-end elements (i.e., consequences and/or desired end state), enabling them to make complete cognitive linkages, and (ii) activate the relevance of an offering to attain personal goals. MECC is put forward as an overarching construct that captures these two dimensions of the cognitive processes that influence perceived service tangibility and, in turn, develops more positive attitude towards the advertisement, and attitude towards the brand.

A complete means-end cognitive connection enables production of mental pictures of a service's attributes (increased visualization) leading to improved perceived tangibility of the advertised service. The study argues that when MECC is strong, the consumer is better able to visualize service benefits and perceived tangibility is increased (MECC $\rightarrow$ PT). Where consumers' MECC is high, there are positive impacts on attitude towards the advertisement $(\mathrm{MECC} \rightarrow$ ATTad) and attitude towards the brand (MECC $\rightarrow$ ATTb). The relationships are hypothesized as follow: 
H1. A high degree of means-end chain connectivity, comprising means-end elements, leads to improved visualization of a service and has a direct positive impact on:
(a) perceived tangibility (MECC $\rightarrow \mathrm{PT})$;
(b) attitude towards the advertisement (MECC $\rightarrow$ ATTad); and
(c) attitude towards the brand (MECC $\rightarrow$ ATTb).

Shimp (2000, p. 164) explained that attitudes are hypothetical constructs, and defined an attitude as "a general and enduring positive or negative feeling toward or evaluative judgment of some person, object or issue." Attitude formation was operationalized as attitude towards the advertisement and attitude towards the brand, given that advertising cognitions often lead to the formation of attitudes (Liu and Stout, 1987; Lutz et al., 1983), and consumers often view all components of a service organization as a single brand name (de Chernatony, 2002). When consumers are able to visualize service features, perceived tangibility of the advertised service improves and is expected to result in a favorable attitude towards the advertisesment (PT $\rightarrow$ ATTad), as ease of evaluating the features and benefits of a service allows them to develop a positive attitude towards the advertisement. It has often been explained in the literature that attitude towards the advertisement has a significant impact on attitude towards the brand (Brown and Stayman, 1992; Gresham and Shimp, 1985). This suggests that a favorable attitude towards the advertisement enhance attitude towards the brand (ATTad $\rightarrow$ ATTb).

H2. An increased level of perceived tangibility has a positive influence on attitude towards the advertisement $(\mathrm{PT} \rightarrow$ ATTad).

H3. A positive attitude towards the advertisement has a positive influence on attitude towards the brand (ATTad $\rightarrow$ ATTb). 


\section{Methodology}

Financial services is the service category chosen for examination, because consumers hold the perception that financial services are highly intangible, even compared to traditional service sectors offerings such as hotels and restaurants, dentistry and hairdressing (Bielen and Sempels, 2003; Laroche et al., 2001; McDougall and Snetsinger, 1990). Further, it has been argued that communication strategies are critical for offerings characterized as high on intangibility, compared with those for which there are more tangible elements (Carlson et al., 2002).

For the financial services consumers, financial return and service quality are two important criteria that affect their decision to open an account with a financial institution (Devlin and Gerrard, 2004; McKechnie, 1992). In an assessment of the relationships between attributes and values, Divine and Lepisto (1998) found that financial services customers often associate banks with two primary values (end-goals): (i) financial security - looking after one's money to provide peace of mind; and (ii) social recognition - feeling of being appreciated and respected by a financial service provider. For the purpose of this study, value is operationalized using Kahle and Kennedy's (1989) List of Values (LOV) as this parsimonious list of consumer value concerns inner self-knowledge and directly influences attitude and behaviors (Beatty et al., 1985; Laverie et al., 1993).

\section{Advertisement Stimuli Manipulation}

Advertisements were created to resemble existing bank advertisements in magazines to allow respondents to evaluate the print advertisements in a manner similar to those in the existing market. A fictitious bank name was created to control for prior knowledge and brand attitude, and the advertisements made use of both textual and pictorial representations in fullcolor A4-size print, as use of both text and images has been found to enhance the 
advertisement's effectiveness compared with text-only advertisements (Laskey et al., 1992; Stafford, 1996).

The advertising stimuli in this study were manipulated according to the guidelines for components of advertising strategy based on a means-end chain conceptualization, with visual and textual cues translated into message components in advertisements (Reynolds and Craddock, 1988). Olson and Reynolds' (1983) suggest that end goals important to consumers should be emphasized in advertisements to facilitate the connection of messages to the consumers' motives. In this study we developed two different experimental advertisements centered on end-goals important to financial services consumers, namely, financial security and social recognition. The two advertisements designed to trigger these personal goals were labelled Type I: financial gain and Type II: service excellence. Tangible elements related to both end-goals were incorporated in the experimental copy because both values are sought after by the financial consumers, but the relative degree of visibility was manipulated. For instance, the main image and descriptors for the Type I advertisement revolved around the end-goal of financial security but a brief description of service excellence was also included though downplayed relative to the main theme of the test copy. A similar manipulation was also performed for the Type II test copy.

\section{Respondents}

The study was carried out in Brunei, where consumer banking is the dominant activity in the financial industry. Together with the local banks, a number of well-established foreign banks contribute to the strong financial infrastructure of the country. Those individuals who draw regular income are eligible to participate in an intercept survey, as they are likely to have a savings and/or current account and are concerned on their financial status. Judgmental sampling was adopted, where respondents were intercepted at three shopping malls located in 
Brunei-Muara district (urban area). Respondents were randomly approached at one of three shopping malls and asked if they are willing to participate in a survey. Those who participated were exposed to one of the two experimental advertisements, and asked to fill in a questionnaire comprising three sections pertaining to (i) demographic profile, (ii) items related to means-end linkages and personal relevance, (iii) items on perceived tangibility, attitude towards the advertisement and attitude towards the brand. After completing the questionnaires, they were thanks for their participation in this survey.

A total of 468 valid questionnaires were collected, where 233 respondents saw Type I ad copy while 235 were exposed to Type II ad copy. Profiles of the respondents were compiled in relation to their gender (56.2 percent are male), age (54.1 percent are 20-29 years old, 24.6 percent are 30-39 years old, 10.9 percent are 40-49 years old and 5.3 percent who are 50-year-old and above), and monthly income (30.5 percent earn less than $\mathrm{B} \$ 2,000,37.6$ percent earn between $\mathrm{B} \$ 2,000$ and $\mathrm{B} \$ 2,999$, and 31.9 percent earn more than $\mathrm{B} \$ 3,000)$.

\section{Measurements}

Means-end linkage (MEL) refers to the perceived strength of means-end connections between attributes, consequences, and values in the minds of consumers. This scale aims to measure the consumers' cognitive connections after exposure to tangible cues, with nine items adapted from Reynolds et al.'s, (1995) measurement pairs of 'adjacent' means-end elements, including four items to measure means-end linkages related to financial security $\left(\mathrm{MEL}_{\mathrm{FS}}\right)$ and five items to assess means-end connections related to social recognition $\left(M_{S R}\right)$. Realization of personal relevance (RPR) represents an activation of a specific value reflecting consumers' recognition that the advertised service is instrumental to achieve their end goal. Items were developed by this study to determine the extent to which consumers recognized that the advertised financial service provider to be instrumental in satisfying their 
personal goals of financial security (five items) and social recognition (five items to measure 'being appreciated' and another five items to measure 'being respected'). MEL $L_{F S}, M_{S R}$, and RPR were measured using a five-point Likert scale ranging from $1=$ strongly disagree to $5=$ strongly agree.

Perceived tangibility (PT) was conceived as the extent to which respondents are able to visualize the benefits and qualities of a financial service after seeing an advertisement. Hill et al.'s (2004) measurement scale was adopted, comprising four items measured using a ninepoint Likert scale ranging from $1=$ strongly disagree to $9=$ strongly agree. Attitude towards the advertisement (ATTad) was measured using five seven-point semantic differential scales: interesting-uninteresting, like-dislike, positive-negative, favorable-unfavorable, and appealing-unappealing; whereby these items were selected from previous studies (Ruiz and Sicilia, 2004; Stafford and Day, 1995). A selection of items from MacKenzie and Lutz (1989) and Stafford and Day (1995) were used to measure attitude towards the brand (ATTb) along five seven-point semantic differential scales; and these items are: good-bad, favorableunfavorable, positive-negative, satisfactory-unsatisfactory, and meant for me-not meant for me.

\section{Data Analysis}

Factor Structure. Exploratory factor analysis (EFA) and confirmatory factor analysis (CFA) were used to determine the psychometric properties of the various measurement scales prior to hypothesis testing using structural equation modeling. Measurement invariance was also used to test if the measurement model is simultaneously fitting for the two independent samples (Kline, 2011). Anderson and Gerbing (1988) pointed out that the benefit of maximum likelihood estimation is theory driven and allows transitions from exploratory to confirmatory analysis. Measurement items were first subjected to principal component 
analysis (PCA). The Kaiser-Meyer-Olson value was .948 , which was above the minimum threshold of .50 (Kaiser, 1974), and Bartlett's test of sphericity was statistically significant ( $p$ $<.001$ ), indicating that factor analysis was suitable for the data used.

PCA revealed seven defined scales with eigenvalues greater than one, explaining 71.0 percent of the total variance. Varimax rotation was performed to identify items that loaded onto each construct. One item measuring $\mathrm{MEL}_{\mathrm{FS}}$ and another three items measuring $\mathrm{RPR}_{\mathrm{SR}}$ were subsequently removed, as they exhibited communality of less than 0.5 or cross-loaded to more than two factors. A second orthogonal rotation was performed and the seven factors accounted for 74.0 percent of the total variance. Cronbach's $\alpha$ value for the seven constructs demonstrated good internal consistency, ranging from 0.752 to 0.961 (see Table 1 ).

\section{<TABLE 1 HERE>}

Next, CFA was used to verify the underlying constructs and assess reliability and validity of each construct. The final measurement scales and fit statistics exhibit good psychometric properties in accordance to Marsh and Hau's (1999) and Garver and Mentzer's (1999) assessments on construct validity. Convergent validity was assessed by factor loadings, composite reliability, and average variance extracted. Results in Table 1 demonstrated scale reliability and convergent validity; factor loadings exceeded the recommended level of .60, composite reliability was above the recommended level of .70 , and average variance extracted was beyond the minimal threshold level of .50 .

The next stage on factor structure assessment involved determining the component structure of the MECC dimension by alternative model comparisons. Three competing nonnested models, shown in Figure 1, were compared and examined along selected model-fit statistics and parsimonious consideration. All three competing models exhibit favorable fit 
statistics (see Table 2). However, indices revealed that Model 2 is superior to the other models, with better parsimonious fit $(\mathrm{AIC}=479.56 ; \mathrm{BIC}=666.24)$, and this illustrate that the MECC dimension is best represented by two second-order factors: (i) $\mathrm{MECC}_{\mathrm{FS}}$, and (ii) $\mathrm{MECC}_{\mathrm{SR}}$. The factor structure in the MECC dimension was then included in the structural equation modeling analysis.

\section{<FIGURE 1 HERE>}

<TABLE 2 HERE>

The final stage is to test for equivalence of the measurement model using multigroup CFA across the two sample groups who were exposed to either Type I or Type II advertisements. Measurement invariance test aims to examine whether Model 2 holds the same factor structure for both groups, and if factor loadings and paths are similar by increasing restrictive constraints. Configural invariance was tested first for both groups (Model i) with no constraint on any parameters. Next, factor loadings were constrained to be equal for both groups to test for metric invariance (Model ii), and finally, paths from latents to indicators were constrained equal in both groups (Model iii) - and these comparisons to examine factor structure is the primary interest of the multigroup invariance test (see Table 3).

When factor loadings were constrained to be equal across sample groups, metric invariance was established, illustrated by the minimal changes to the model fit index (see Table 3). Fit statistics improved slightly when path constraints were also imposed to the model, and there is no significant difference between groups when factor loadings and paths were constrained to be equal in Model iii $(p>.05)$. Therefore, the information suggests that the factor structure displayed in Model 2 holds for both sample groups who saw either Type I or Type II advertisements. 
<TABLE 3 HERE>

Structural Equation Modeling. Structural equation modeling was used at the final stage of the analysis to assess path structures, because it estimates a series of separate but interdependent multiple regression equations simultaneously in a structural model (Hair et al., 1998). Path analysis provides insights into consumer cognition after exposure to the experimental advertisement, and the extent of their evaluations of the psychological aspects of financial services and advertising effectiveness.

\section{Findings}

Favorable model-fit indices indicate acceptance of the proposed conceptualization of MECC and advertising effectiveness for financial services, which builds on respondents' visualization of intangible aspects of financial services, thus aiding their evaluations (see Figure 2). Inspection of the modification indices did not reveal substantial cross-loadings between latent constructs. The two higher-order constructs (i.e., $\mathrm{MECC}_{\mathrm{FS}}$ and $\mathrm{MECC}_{\mathrm{SR}}$ ) in the MECC dimension suggests that respondents expend cognitive efforts directed at each value separately, in such way that they were able to make specific connections with the respective value elements. It is also important to note that, at the same time, simultaneous comprehension of both means-end values occurred in the respondents' mind ( $r=.406, p$ $<.001$ ) (see Figure 2). The MECC components have considerable influence on perceived tangibility $\left(\mathrm{R}^{2}=.434\right)$, attitude towards the advertisement $\left(\mathrm{R}^{2}=.562\right)$, and attitude towards the brand $\left(\mathrm{R}^{2}=.668\right)$ which explain the importance of communicating value to improve service advertising effectiveness. 
<FIGURE 2 HERE>

The loadings of the $\mathrm{MECC}_{\mathrm{FS}}$ construct to $\operatorname{MEL}_{\mathrm{FS}}(\beta=.606, p<.001)$ and $\mathrm{RPR}_{\mathrm{FS}}(\beta$ $=.823, p<.001)$ suggest two simultaneous cognitions: (i) activation of means-end connections where respondents were able to link interest rate (attribute) to financial gains/saving more (positive consequences) and then to financial security (desired end-goals), and (ii) realization of personal relevance for enhanced financial security. Likewise, the loadings of the $\mathrm{MECC}_{\mathrm{SR}}$ construct to $\operatorname{MEL}_{\mathrm{SR}}(\beta=.675, p<.001)$ and $\operatorname{RPR}_{\mathrm{SR}}(\beta=.984, p$ $<.001)$ demonstrates that respondents translated cues of customer service into a mode of linkage between friendly/helpful staff (attribute) and feeling comfortable asking for financial advice (positive consequence) and then to feeling of being respected and having a sense of belonging to the financial institution (desired end-goals). At the same time, respondents recognized the financial service to be in line with their desired goals of social recognition from financial service providers.

The parameter coefficients of the second-order constructs in the MECC dimension highlight two important findings of their influence on visualizing service aspects and attitudinal responses. While all four relationships between the first and second-order constructs are statistically significant (i.e., important components affecting the dependent variables), the higher factor loadings of $\mathrm{MECC}_{\mathrm{SR}}$ to $\mathrm{MEL} \mathrm{LR}_{\mathrm{S}}$ and $\mathrm{RPR}_{\mathrm{SR}}$, compared to $\mathrm{MECC}_{\mathrm{FS}}$, reflect that social recognition as an element in advertisement has greater relative importance in the means-end dimension and influence in predicting PT, ATTad and ATTb. This seems to imply 'stronger' means-end cognitions concerning social recognition occurred, where respondents may have better comprehension of excellent service and considered social recognition to be more personally relevant, compared to financial security. Meanwhile, the MECC loading coefficients to the RPR constructs (i.e., $\mathrm{RPR}_{\mathrm{FS}}$ and $\mathrm{RPR}_{\mathrm{SR}}$ ) were found to be 
higher compared to the MEL constructs, which revealed that realization of personal relevance plays a more salient role in the MECC dimension than one's ability to make means-end linkages. This suggests that attainment of personal goals prevails over the ability to link attributes to consequences to values during evaluation of advertisements.

Hypothesis 1 is partially supported. Tangible cues on recognition and appreciation of customers by financial service provider positively impact on (a) perceived tangibility ( $\beta$ $=.183, p<.001)$, (b) attitude towards the advertisement $(\beta=.188, p<.001)$, and (c) attitude towards the brand $(\beta=.111, p<.001)$. Meanwhile, the relative importance of means-end cognition for financial security positively impacts on perceived tangibility $(\beta=.563, p<.001)$ and attitude towards the brand $(\beta=.267, p<.001)$, but not on attitude towards the advertisement $(\beta=.108, p>.05)$.

Hypothesis 2 was supported, indicating that respondents' evaluation of financial services was facilitated by improving visualization of psychological aspects of service features which, in turn, had a positive impact on attitude towards the advertisement $(\beta=.575$, $p<.001)$. Hypothesis 3 predicted that a positive attitude towards the advertisement because of an increased level of perceived tangibility of the financial service has a positive impact on attitude towards the brand. The finding supported this hypothesis, with a standardized path coefficient of .573 and was statistical significance at the .001 level.

\section{Discussion}

This study provides a framework to understand that exposure to relevant visual cues in advertisements leads to higher levels of cognitive connectivity which, in turn, increases the vividness, or perceived tangibility, of a service. Cognitive connectivity is conceptualized to comprise two dimensions - consumers' realization of personal relevance and their ability to complete means-end hierarchical linkages between the adjacent elements - and MECC is a 
construct captures these two aspects of elaboration. Complete cognitive evaluations of service cues in advertisements improve visualization, which positively affect attitudes towards the advertisement and towards the brand. This conceptualization integrates knowledge of advertising message content that enables consumers to visualize an intangible service (Stafford, 1996; Tripp, 1997) and of advertising content that facilitates means-end chain connections (Gutman and Miaoulis, 2003). Further it extends the research into elaboration processes for advertising that facilitate means-end chain connections by also recognizing the role of personal relevance in cognitive connectivity (Graeff, 1997).

The empirical study provides evidence that when advertising strategies designed to enable consumers to elaborate on message content facilitate higher levels of MECC, there is a significant positive impact on the vividness of intangible aspects of a service. Examining the relationships within the context of financial services suggests that respondents do perceive different value types from visual elements, in this case, financial security and social recognition. Complete means-end connections of both values positively affect respondents' visualization of a service and their attitudes to the advertisement and the financial brand. The empirical findings in this context also reveal that visual elements of financial security have a greater effect on visualization and attitude towards the service brand, while tangible cues concerning social recognition have a stronger influence on attitude towards the advertisement.

There are three important findings from the parameter estimates in the MECC dimension. Firstly, the MECC construct illustrates that means-end connectivity of financial security and social recognition occurred simultaneously in the minds of the respondents. However, there are differences on the degree of cognitive connectivity for the two types of values. Specifically, results show stronger bonds between attribute, consequences and value for components related to social recognition, implying that respondents are able to make better connections of visual elements related to service quality. Secondly, the higher degree 
of personal relevance for social recognition indicates that tangible cues of service excellence is an important mean to attain end-goals of being recognized by others in the society, compared to financial security. Thirdly, the findings reveal that personal relevance has a greater influence as a MECC dimension, which suggests that recognizing a product as personally relevant to achieve end-goals facilitate greater consumers' visualization of services after they saw a service advertisement.

It is, therefore, important to maximize value perceptions in communications in a way that improves the clarity of service features. Previous research has noted that consumers can find bank advertisements to be overwhelming, confusing and undifferentiated between different financial service providers (Ries and Ries, 2003). Perhaps this is due to consumers' inability to differentiate between financial products offered by different financial institutions, but they may be better able to relate to the intimacy of a relationship with bank personnel and service quality cues. For financial services managers, developing visual elements of communications that are based on appreciating and recognizing customers' patronage motives is likely to be meaningful to consumers, and help the financial firm stand out among the clutter of banking advertisements in the marketplace.

This study found that a financial service brand attitude may be further enhanced by increasing consumers' perceived personal relevance through relevant advertising cues, and in this context: financial security and social recognition. Whether visual elements are manipulated around financial gain or service excellence, findings here suggest that financial service managers should aim at stimulating perceived personal relevance to allow better connections with their customers. Financial service organizations tend to deploy advertisements on service quality, atmospherics, innovativeness, financial value and family value in advertising (Albers-Miller and Straughan, 2000; Lee et al. 2011); thus, financial managers could make the message content more explicit in such way as to allow target 
audiences to visualization the benefits more easily. For instance, innovativeness (modern innovation, advance technology or neat and orderly environment) as an appeal could use texts and images to spell out to the customers that the firm's continual innovative enhancement is aim to ensure that their financial asset is safe with the organization (financial security assurance).

Deployment of visual elements in advertising contents of financial institutions ought to be based on the objectives they are trying to achieve. For instance, tangible cues of financial security is likely to increase awareness of the financial products and generate likeability towards the advertisement; on the other hand, emphasizing appreciating and valuing the presence of the customers would be more effective to enhance attitude towards the brand. Customers are open to non-human interaction when acquiring savings and investment products (Lee, 2002), and there are increased opportunity to reinforce the service brand on the World Wide Web using appropriate visual elements (An, 2014). Managers of financial institutions could capitalize on advertising cues aimed to induce personal relevance for enhanced financial security or reinforce the financial brand in order to stimulate online purchase intention.

In addition to its theoretical contributions, this study demonstrates a quantitative approach to evaluating the connections between means-end elements through the MECC indicators, which affords an alternative method to the qualitative laddering technique that dominate means-end chain analyses (Gengler and Reynolds, 1995; Klanac, 2012). In addition to testing cognitive connections relevant to different types of value improve the vividness of a service, within a particular context, it is also worth examining whether messages focused upon specific forms of value or message combinations can improve the overall effectiveness of an advertising campaign. 


\section{Limitations and Suggestions for Future Research}

The empirical focus upon financial services means that it was limited to examining advertising effectiveness for a type of service that primarily offers functional value by addressing the financial needs of consumers. Future research is needed to test the robustness of the MECC model by investigating the impact of values and message content across different categories of services. Interesting contrasts may emerge, for instance, through examination of the effects of message elements for service offerings focused upon experiential value, where tangible cues of physical representation (e.g., buildings, uniforms, equipment) are less visible to consumers, for example, travel and tourism, distance learning, and entertainment. More broadly, the growing acknowledgement that service is central marketing exchange means that more research is sorely needed to provide insight into ways to shape messages that effectively communicate about propositions to support consumers value co-creation through offers that are, in essence, intangible.

For parsimonious reasons, this study manipulated two experimental copies with visual stimuli of two values desired by the financial consumers: financial security and social recognition. Other values that consumers associate with financial services which may affect advertising effectiveness were not included. Future research should examine different types of values (such as family value or convenience) or different forms of financial products (such as credit cards, mortgages, mutual funds, insurance or retirement funds) to draw greater understandings on cognitive intensity that may improve visualization strategy and enhance service advertising.

This study involved respondents participating in a survey, which is a form of forced exposure setting, subjecting respondents to a high analytical state in search of cognitive responses to justify their evaluations (Stafford and Day; 1995). It is necessary to manipulate the experimental copies to mitigate possible contextual effects, however, in reality, 
consumers often do not give such attention to advertisements. Noting this methodology limitation, future research should consider conducting experimental tests in a natural comfortable setting where findings are more realistic compared to forced exposure (Lloyd and Clancy, 1991; Moorman et al., 2007).

This study was conducted in Brunei, with a high adult literacy rate estimated at 97.8 percent in 2015 (Ministry of Education, 2015). Literacy affects one's cognitive ability, where higher level of literacy enables "more cognitive focus on comprehension as opposed to decoding" (de Lemos, 2002, pp. 7), thus, respondents in this study are highly likely to understand the test stimuli and undergone a high elaboration process (ELM) (Petty and Cacioppo, 1986) of decoding and interpreting the embedded messages. Future studies could be extended to countries with different literacy rate to determine the effects of value communication technique in visualization and advertising on cognitive responses, and to provide insights for international financial service managers.

\section{References}

Abernethy, A.M. and Butler, D.D. (1992), "Advertising information: Services versus products", Journal of Retailing, Vol. 68 No. 4, pp. 398-419.

Abernethy, A.M., Gray, J.I. and Butler, D.D. (1997), "Radio advertising information strategy: Differences between services and products", Journal of Services Marketing, Vol. 11 No. 5, pp. 344-357.

Albers-Miller, N.D. and Straughan, R.D. (2000), "Financial services advertising in eight nonEnglish speaking countries", International Journal of Bank Marketing, Vol. 18 No. 7, pp. 347-357.

An, D. (2014), "Tangibilizing services through visual tangible cues in corporate web sites: A six-country cross-cultural analysis", Journal of Services Marketing, Vol. 28 No. 7 , pp.566-579.

Anderson, J.C. and Gerbing, D.W. (1998), "Structural equation modeling in practice: A review and recommended two-step approach", Psychological Bulletin, Vol. 103 No. 3, pp. 411-423. 
Bateson, J.E.G. (1979), "Why we need service marketing", in Ferrell, O.C., Brown, S.W. and Lamb Jr., C.W. (Eds.), Conceptual and Theoretical Developments in Marketing, Conference Proceedings Series, American Marketing Association, Chicago.

Batra, R. and Ray, M. (1985), "How advertising works at contact", in Alwitt, L.F. and Mitchell, A.A. (Eds.), Psychological Processes and Advertising Effects, Hillsdale, Lawrence Eribaum Associates, NJ.

Beatty, S.E., Kahle, L.R., Homer, P. and Misra, S. (1985), "Alternative measurement approaches to consumer values: The List of Values and the Rokeach Value Survey", Psychology and Marketing, Vol. 2 No. 3, pp. 181-200.

Berry, L.L. (1980), “Services marketing is different”, Business, Vol. 30 No. 3, pp. 24-29.

Berry, L.L. and Clark, T. (1986), "Four ways to make services more tangible", Business, Vol. 36, pp. 53-54.

Bielen, F. and Sempels, C. (2003), "The dimensionality of the concept of intangibility: A critical analysis", working paper, Louvian School of Management, Universite Catholique de Louvain.

Botschen, G., Thelen, E.M. and Pieters, R. (1999), "Using means-end structures for benefit segmentation: An application to services", European Journal of Marketing, Vol. 33 No.1/2, pp. 38-58.

Brown, S.P. and Stayman, D.M. (1992), "Antecedents and consequences of attitude toward the ad: A meta-analysis", Journal of Consumer Research Vol. 19 No.1, pp. 34-51.

Carlson, L.G., Grove, S.J. and Dorsch, M.J. (2002), "Compensating for services intangibility: A study of the incidence of IMC at the tactical level", American Marketing Association Conference Proceedings, Vol. 13, pp. 94.

Celsi, R.L. and Olson, J.C. (1988), "The role of involvement in attention and comprehension processes", Journal of Consumer Research, Vol. 15 No. 2, pp. 210-224.

Clow, K. E., James, K. E., Kranenburg, K. E., and Berry, C. T. (2006), "The relationship of the visual element of an advertisement to service quality expectations and source credibility”, Journal of Services Marketing, Vol. 20 No. 6, pp. 404-411.

Culter, B.D. and Javalgi, R.G. (1993), "Analysis of print ad features: Services versus products", Journal of Advertising Research, Vol. 33 No. 2, pp. 62-69.

de Chernatony, L. (2002), "Would a brand smell any sweeter by a corporate name?", Corporate Reputation Review, Vol. 5 No. 2/3, pp. 114-132.

de Lemos (2002), "Closing the gap between research and practice: Foundations for the acquisition of literacy" available at http://research.acer.edu.au/literacy_numeracy_reviews/1/ (accessed 14 June 2016).

Décaudin, J. and Lacoste, D. (2010), "Are services advertised differently? An empirical examination", Journal of Services Marketing, Vol. 24 No. 7, pp. 546-553. 
Décaudin, J. and Lacoste, D. (2016), "Services advertising: Showcase the customer!", Journal of Marketing Communications, Vol. 22 No. 1, pp. 1-17.

Devlin, J.F., and Gerrard, P. (2004), "Choice criteria in retail banking: An analysis of trends", Journal of Strategic Marketing, Vol. 12 No. 1, pp. 13-27.

Devlin, J.F, Gwynne, A.L. and Ennew, C.T. (2002), "The antecedents of service expectations", The Service Industries Journal, Vol. 22 No. 4, pp. 117-136.

Divine, R.L. and Lepisto, L. (1998), "A means-end analysis of linkages between bank attributes and consumer values: A correlational approach", Journal of Marketing Management, Vol. 8 No. 1, pp. 72-79.

Garver, M.S. and Mentzer, J.T. (1999), "Logistics research methods: Employing structural equation modeling to test for construct validity", Journal of Business Logistics, Vol. 20 No. 1, pp. 33-56.

George, W.E. and Berry, L.L. (1981), "Guidelines for the advertising of services", Business Horizons, Vol. 24 No. 4, pp. 52-56.

Gengler, C.E. and Reynolds, T.J. (1995), "Consumer understanding and advertising strategy: Analysis and strategic translation of laddering data", Journal of Advertising Research, Vol. 35 No. 4, pp. 19-32.

Graeff, T.R. (1997), “Comprehending product attributes and benefits: The role of product knowledge and means-end chain inferences", Psychology \& Marketing, Vol. 14 No. 2, pp. 163-183.

Gresham, L.G. and Shimp, T.A. (1985), "Attitude toward the advertisement and brand attitudes: A classical conditioning perspective", Journal of Advertising, Vol. 14 No. 1, pp. 10-17.

Grönroos, C. and Gummerus, J. (2014), "The service revolution and its marketing implications: Service logic vs service-dominant logic", Managing Service Quality, Vol. 24 No. 3, pp. 206-229.

Grunert, K.G. and Grunert, S.C. (1995), "Measuring subjective meaning structures by the laddering method: Theoretical considerations and methodological problems", International Journal of Research in Marketing, Vol. 12 No. 3, pp. 209-225.

Gummerus, J. (2013), "Value creation processes and value outcomes in marketing theory: Strangers or siblings?", Marketing Theory, Vol. 13 No. 1, pp. 19-46.

Gutman, J. (1982), “A means-end chain model based on consumer categorization processes", Journal of Marketing, Vol. 46 No. 1, pp. 60-72.

Gutman, J. (1997), "Means-end chains as goal hierarchies", Psychology and Marketing, Vol. 14 No. 6, pp. 545-560.

Gutman, J. and Miaolis, G. (2003), "Communicating a quality position in service delivery: An application in higher education", Managing Service Quality: An International Journal, Vol. 13 No. 2, pp. 105-111. 
Hair, J.F., Anderson, R.E., Tatham, R.L. and Black, W.C. (1998), Multivariate Data Analysis, 5ed., Prentice-Hall, New Jersey.

Heinze, J., Thomann, M. and Fischer, P. (2017), "Ladders to m-commerce resistance: A qualitative means-end approach", Computers in Human Behavior, Vol. 73 August, pp. 362-374.

Hellén, K. and Gummerus, J. (2013), "Re-investigating the nature of tangibility/intangibility and its influence on consumer experiences", Journal of Service Marketing, Vol. 24 No. 2, pp. $130-150$.

Hill, D.J., Blodgett, J., Baer, R. and Wakefield, K. (2004), "An investigation of visualization and documentation strategies in services advertising", Journal of Service Research, Vol. 7 No. 2, pp. 155-166.

Hirschman, E.C. (1980), "Attributes of attributes and layers of meaning", Advances in Consumer Research, Vol. 7 No. 1, pp.7-12.

Ho, C.L., Lin, P.Y. and Huang, S.C. (2014), "Exploring Taiwanses working holiday-makers' motivations: An analysis of means-end hierarchies", Journal of Hospitality \& Tourism Research, Vol. 38 No. 4, pp. 463-486.

Houston, M.B. and Walker, B.A. (1996), "Self-relevance and purchase goals: Mapping a consumer decision", Journal of the Academy of Marketing Science, Vol. 24 No. 3, pp.232-245.

Jaeger, S.R. and Macfie, H.J.H. (2001), "The effect of advertising format and means-end information on consumer expectations for apples", Food Quality Preference, Vol. 12 No. 3, pp. 189-205.

Jiang, S., Scott, N. and Ding, P. (2015), "Using means-end chain theory to explore travel motivation: An examination of Chinese outbound tourists", Journal of Vacation Marketing, Vol. 25 No. 1, pp. 87-100.

Kahle, L.R. and Kennedy, P. (1989), "Using the List of Values (LOV) to understand consumers", Journal of Consumer Marketing, Vol. 6 No. 3, pp. 5-12.

Kaiser, H. (1974), “An index of factorial simplicity”, Psychometrika, Vol. 39, pp. 31-36.

Kindström, D., Kowalkowski, C. and Nordin, F (2012), "Visualizing the value of servicebased offerings: Empirical findings from the manufacturing industry", Journal of Business \& Industrial Marketing, Vol. 27 No. 7, pp. 538-546.

Klanac, N.G. (2012), "Types of linkages between service characteristics and customer consequences", European Journal of Marketing, Vol. 46 No. 3/4, pp. 313-330.

Klanac, N.G. (2013), “An integrated approach to customer value: A comprehensive-practical approach", Journal of Business Marketing Management, Vol. 6 No. 1, pp. 22-37.

Klenosky, D.B., Gengler, C.E. and Mulvey, M.S. (1999), "Understanding the factors influencing ski destination choice: A means-end analytic approach", Journal of Leisure Research, Vol. 12 No. 4, pp. 362-379. 
Kline, R.B. (2011), Principles and Practice of Structural Equation Modeling, 3ed., The Guilford Press, New York.

Kuisma, T., Laukkanen, T. and Hiltunen, M. (2007), "Mapping the reasons for resistance to Internet banking: A means-end approach", International Journal of Information Management, Vol. 27 No. 2, pp. 75-85.

Laroche, M., Bergeron, J. and Goutaland, C. (2001), "A three-dimensional scale of intangibility", Journal of Service Research, Vol. 4 No. 1, pp. 26-38.

Laroche, M., Bergeron, J. and Goutaland, C. (2003), "How intangibility affects perceived risk: The moderating role of knowledge and involvement", Journal of Services Marketing, Vol. 17 No. 2, pp. 122-140.

Laskey, H.A., Seaton, B. and Nicholls, J.A.F. (1992), "Strategy and structure in bank advertising: An empirical test", International Journal of Bank Marketing, Vol. 10 No. 3, pp.3-9.

Laverie, D.A., Kleine III, R.E. and Kleine, S.S. (1993), "Linking emotions and values in consumption experiences: An exploratory study", Advances in Consumer Research, Vol. 20 No. 1, pp. 70-75.

Lee, J. (2002), "A key to marketing financial services: the right mix of products, services, channels and customers", Journal of Services Marketing, Vol. 16 No. 3, pp. 238-258.

Lee, T., Chung, W. and Taylor, R.E. (2011), "A strategic response to the financial crisis: An empirical analysis of financial services advertising before and during the financial crisis", Journal of Services Marketing, Vol. 25 No. 3, pp. 150-164.

Liu, S.S. and Stout, P.A. (1987), "Effects of message modality and appeal on advertising acceptance", Psychology and Marketing, Vol. 4 No. 3, pp. 167-187.

Lloyd, D.W. and Clancy, K.J. (1991), "Television program involvement and advertising response: Some unsettling implications for copy research", Journal of Consumer Marketing, Vol. 8 No. 4, pp. 61-74.

Lovelock, C. and Wirtz, J. (2004), Services Marketing: People, Technology, Strategy, 5th ed., Prentice-Hall, Upper Saddle River, NJ.

Lutz, R.J., Mackenzie, S.B. and Belch, G.E. (1983), "Attitude toward the ad as a mediator of advertising effectiveness: Determinants and consequences", Advances in Consumer Research, Vol. 10 No. 1, pp. 532-539.

MacKenzie, S.B. and Lutz, R.J. (1989), "An empirical examination of the structural antecedents of attitude toward the ad in an advertising pretesting context", Journal of Marketing, Vol. 53 No. 2, pp. 48-65.

Marsch, H.W. and Hau, K.T. (1999), "Confirmatory factor analysis: Strategies for small sample sizes", in Hoyle, R.H. (Ed.), Statistical Issues for Small Sample Research, Sage, Thousand Oaks, CA. 
Matilla, A.S. (1999), "Do emotional appeals work for services?", International Journal of Service Industry Management, Vol. 10 No. 2, pp. 292-306.

McDougall, G.H.G. and Snetsinger, D.W. (1990), "The intangibility of services: Measurement and competitive perspectives", Journal of Services Marketing, Vol. 4 No. 4, pp. 27-40.

McKechnie, S. (1992), "Consumer buying behaviour in financial services: An overview", International Journal of Bank Marketing, Vol. 10 No. 5, pp. 4-12.

McQuarrie, E.F. and Phillips, B.J. (2005), "Indirect persuasion in advertising”, Journal of Advertising, Vol. 34 No. 2, pp.7-20.

Ministry of Education (2015), "Education for All 2015 National Review Report: Brunei Darussalam", paper presented at the World Education Forum, 19-22 May, Incheon, Republic of Korea, available at: http://unesdoc.unesco.org/images/0023/002305/230503e.pdf (accessed 13 June 2016).

Moorman, M., Neijens, P.C. and Smit, E.G. (2007), "The effects of program involvement on commercial exposure and recall in a naturalistic setting", Journal of Advertising, Vol. 36 No. 1, pp. 121-137.

Mortimer, K. (2000), "Are services advertised differently? An analysis of the relationship between product and service types and the information content of their advertisement", Journal of Marketing Communications, Vol. 6 No. 2, pp. 121-134.

Mortimer, K. (2008), "Identifying the components of effective service advertisements", Journal of Services Marketing, Vol. 22 No. 2, pp. 104-113.

Mulvey, M S., Olson, J.C., Celsi, R.L. and Walker, B.A. (1994), "Exploring the relationships between means-end knowledge and involvement", Advances in Consumer Research, Vol. 21 No. 1, pp. 51-57.

Murray, K.B. (1991), "A test of services marketing theory: Consumer information acquisition activities", Journal of Marketing, Vol. 55 No.1, pp.10-25.

Olson, J.C. and Reynolds, T.J. (1983), “Understanding consumers' cognitive structures: Implications for advertising strategy", in Percy, L. and Woodside, A.G. (Eds), Advertising and Consumer Psychology, Lexington Books, MA.

Pai, P. and Arnott, D. (2013), "User adoption of social networking sites: Eliciting uses and gratifications through a means-end approach", Computers in Human Behavior, Vol. 29 No. 3, pp. 1039-1053.

Payne, A.F., Storbacka, K. and Frow, P. (2008), "Managing the co-creation of value", Journal of Academy of Marketing Science, Vol. 36 No. 1, pp. 83-96.

Petty, R.E. and Cacioppo, J.T. (1981), "Issue involvement as moderator of the effects on attitude of advertising content and context", Advances in Consumer Research, Vol. 8 No. 1, pp. 20-24. 
Petty, R.E., Cacioppo, J.T. and Schumann, D. (1983), "Central and peripheral routes to advertising effectiveness: The moderating role of involvement", Journal of Consumer Research, Vol. 10 No. 2, pp. 135-144.

Petty, R.E. and Cacioppo, J.T. (1986), "The elaboration likelihood model of persuasion", Advances in Experimental Social Psychology, Vol. 19, pp. 123-205.

Pickett, G.M., Grove, S.J. and LaBand, D. (2001), "The impact of product type and parity on the informational content of advertising", Journal of Marketing, Vol. 9 No. 3, pp. 32-43.

Reynolds, T.J. and Craddock, A.B. (1988), "The application of the MECCAS model to the development and assessment of advertising strategy: A case study", Journal of Advertising Research, Vol. 28 No. 2, pp. 43-54.

Reynolds, T.J. and Rochon, J.P. (1991), "Means-end based advertising research: Copy testing is not strategy assessment", Journal of Business Research, Vol. 22 No. 2, pp. 131-142.

Reynolds, T.J., Gengler, C.E. and Howard, D.J. (1995), "A means-end analysis of brand persuasion through advertising", International Journal of Research in Marketing, Vol. 12 No. 3, pp. 257-266.

Ries, A. and Ries, L. (2003), "Financial planning has a PR problem", Journal of Financial Planning, Vol. 16 No. 2, pp. 16-18.

Rosenzweig, E. and Gilovich, T (2012), “Buyer's remorse or missed opportunity? Differential regrets for material and experiential purchases", Journal of Personality and Social Psychology, Vol. 102 No. 2, pp. 215-223.

Ruiz, S. and Sicilia, M. (2004), "The impact of cognitive and/or affective processing styles on consumer response to advertising appeals", Journal of Business Research, Vol. 57 No. 6, pp. 657-664.

Shimp, T.A. (2000), Advertising Promotion: Supplementary Aspects of Integrated Marketing Communication, 6th ed. The Dryden Press.

Song, S.S. and Kim, M. (2012), "Does more mean better? An examination of visual product presentation in e-retailing", Journal of Electronic Commerce Research, Vol. 13 No. 4, pp. 345-355.

Stafford, M.R. (1996), "Tangibility in services advertising: An investigation of verbal versus visual cues”, Journal of Advertising, Vol. 25 No. 3, pp. 13-18.

Stafford, M.R. (2005), "International services advertising: Defining the domain and reviewing the literature", Journal of Advertising, Vol. 34 No. 1, pp. 65-86.

Stafford, M.R. and Day, E. (1995), "Retail services advertising: The effects of appeal, medium and service", Journal of Advertising, Vol. 24 No. 1, pp. 57-71.

Stern, B.l. and Resnik, A.J. (1991), "Informational content in television advertising: A replication and extension", Journal of Advertising Research, Vol. 31 No. 3, pp.36-46. 
Tarn, D.D.C (2005), "Raising services' tangibility in foreign markets via marketing: A model construction and a cross-national comparative empirical survey", International Marketing Review, Vol. 22 No. 3, pp. 327-352.

Tripp. C. (1997), "Services advertising: An overview and summary of research, 1980-1995", Journal of Advertising, Vol. 26 No. 4, pp. 21-38.

Vargo, S.L. and Lusch, R.F. (2004), "Evolving to a new dominant logic for marketing", Journal of Marketing, Vol. 68 No. 1, pp. 1-17.

Woodruff, R.B. (1997), "Customer value: The next source for competitive advantage", Journal of the Academy of Marketing Science, Vol. 25 No. 2, pp. 139-153.

Zhang, H., Sun, J., Liu, F. and Knight, J.G. (2014), "Be rational or be emotional: Advertising appeals, service types and consumer responses", European Journal of Marketing, Vol. 48 No. 11/12, pp. 2105-2126.

Zinkhan, G.M., Johnson, M. and Zinkhan, F.C. (1992), "Differences between product and services television commercials", Journal of Services Marketing, Vol. 6 No. 3, pp. 5966. 
Table 1 Assessments on Construct Validity

\begin{tabular}{lrrr}
\hline & & \multicolumn{2}{c}{ Convergent Validity } \\
\cline { 3 - 4 } $\begin{array}{c}\text { Measurement } \\
\text { Scales }\end{array}$ & $\begin{array}{r}\text { Cronbach's } \\
\text { Alpha }\end{array}$ & $\begin{array}{r}\text { Composite } \\
\text { Reliability }\end{array}$ & $\begin{array}{r}\text { Average Variance } \\
\text { Extracted }\end{array}$ \\
\hline MEL $_{\mathrm{FS}}$ & 0.752 & 0.753 & 0.504 \\
MEL $_{\mathrm{SR}}$ & 0.923 & 0.88 & 0.699 \\
RPR $_{\mathrm{FS}}$ & 0.837 & 0.766 & 0.515 \\
RPR $_{\mathrm{SR}}$ & 0.911 & 0.713 & 0.581 \\
PT & 0.961 & 0.961 & 0.862 \\
ATTad & 0.94 & 0.909 & 0.762 \\
ATTb & 0.922 & 0.903 & 0.758 \\
\hline
\end{tabular}

Notes: $\mathrm{MEL}=$ means-end linkages; $\mathrm{RPR}=$ realization of personal relevance; $\mathrm{FS}=$ financial security; SR = social recognition; PT = perceived tangibility; ATTad $=$ attitude towards the advertisement; $\mathrm{ATTb}=$ attitude towards the brand.

Fit statistics: $\chi^{2}=1028.988, d f=506, p<.001, \mathrm{GFI}=.884, \mathrm{NFI}=.921$, TLI $=.954, \mathrm{CFI}$ $=.958$, RMSEA $=.047$

Table 2 Model Fitness Indicators for Three Competing Measurement Models

\begin{tabular}{rrrrrrrrr}
\hline & $\chi^{2}$ & $d f$ & $p$ & GFI & CFI & RMSEA & AIC & BIC \\
\hline Model 1 & 478.401 & 166 & $<.001$ & .910 & .940 & .063 & 566.401 & 748.934 \\
Model 2 & 389.556 & 165 & $<.001$ & .922 & .957 & .054 & 479.556 & 666.237 \\
Model 3 & 453.688 & 165 & $<.001$ & .913 & .945 & .061 & 543.688 & 730.369 \\
\hline
\end{tabular}

Table 3 Model Fitness Statistics on Measurement Invariance

\begin{tabular}{clrrrrrrr}
\hline Model & $\begin{array}{l}\text { Parameter } \\
\text { constrained }\end{array}$ & $\chi^{2}$ & $d f$ & $\Delta \chi^{2}$ & $\Delta d f$ & $p$ & CFI & RMSEA \\
\hline i & None & 626.981 & 330 & - & - & - & 0.938 & 0.044 \\
ii & Factor & 643.361 & 346 & 16.380 & 16 & 0.427 & 0.938 & 0.043 \\
iii & $\begin{array}{l}\text { loadings } \\
\text { Factor loadings, } \\
\text { paths }\end{array}$ & 635.007 & 348 & 8.026 & 18 & 0.978 & 0.94 & 0.042 \\
\hline
\end{tabular}


Figure 1 Competing Measurement Models of the MECC Dimension

Model 1

(Single second-order factor)

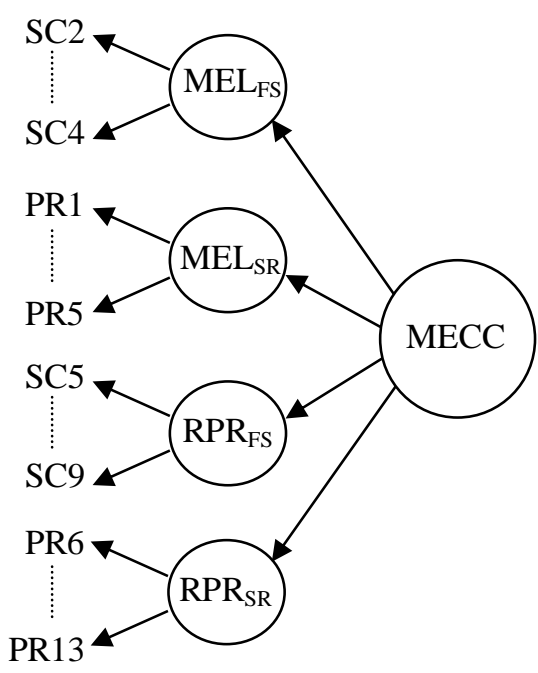

Model 2

(Two second-order factors)

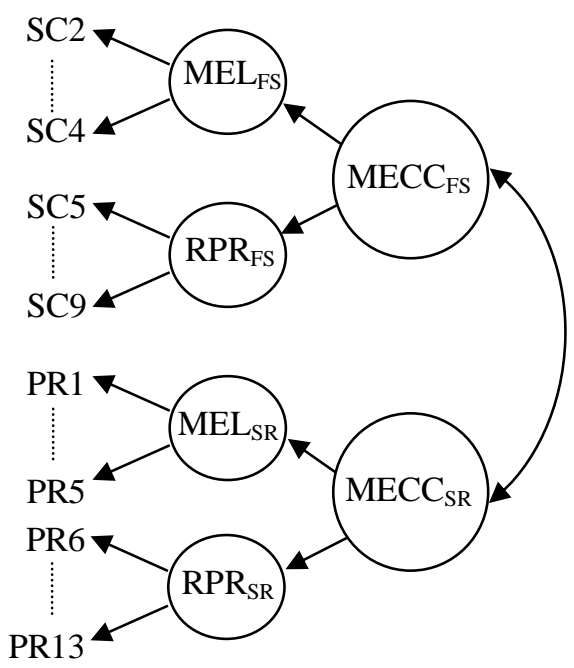

Model 3

(Two second-order factors)

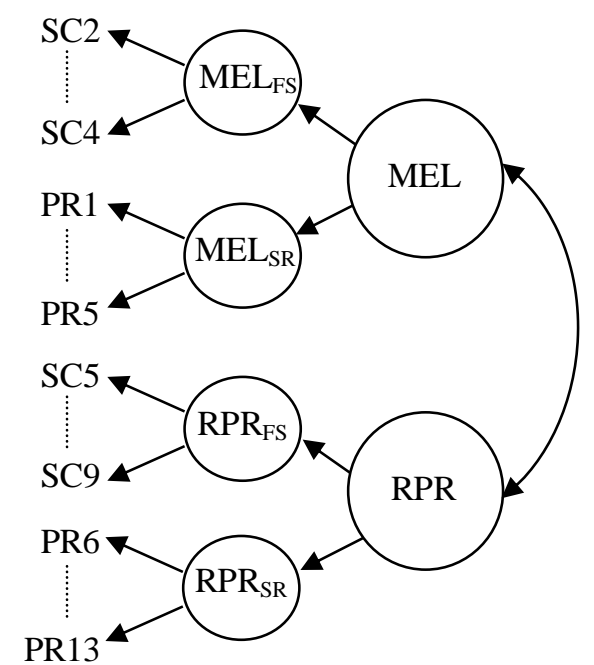

Notes: $\mathrm{MECC}=$ means-end chain connectivity; $\mathrm{FS}=$ financial security; $\mathrm{SR}=$ social recognition; $\mathrm{MEL}=$ means-end linkages; $\mathrm{RPR}=$ realization of personal relevance 
Figure 2 Standardized Estimates of the Structural Model

\section{Components of the MECC dimension}

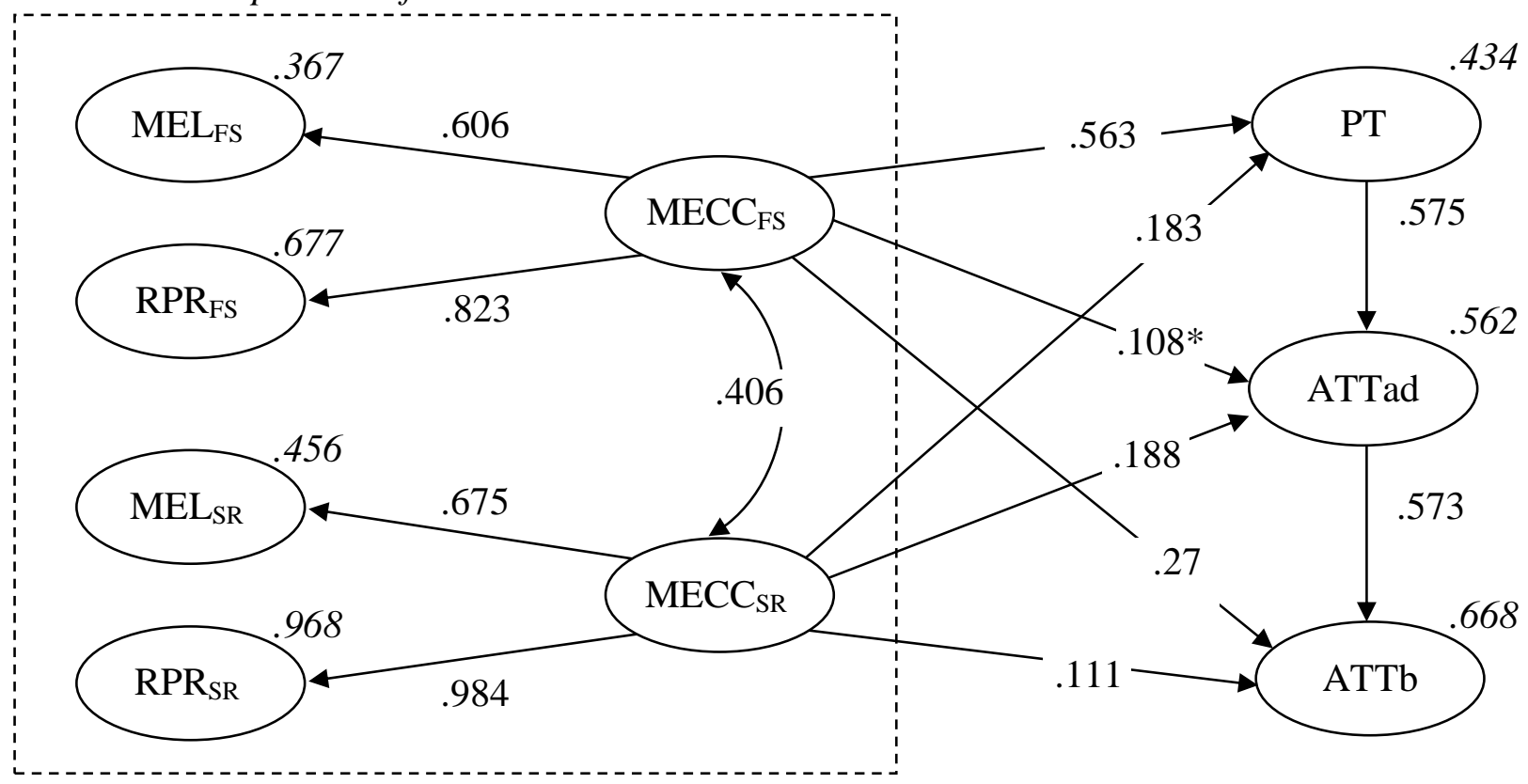

Notes: $*$ Parameter not significant at $p=.05$.

Numbers in italic represents squared multiple correlation $\left(\mathrm{R}^{2}\right)$.

Selected fit statistics: $\chi^{2}(514, n=468)=1081.983 ; p<.001 ; \mathrm{GFI}=.879 ; \mathrm{NFI}=.917$;

$\mathrm{TLI}=.95 ; \mathrm{CFI}=.954 ; \mathrm{RMSEA}=.049$ 